\title{
Carnosic acid prevents the migration of human aortic smooth muscle cells by inhibiting the activation and expression of matrix metalloproteinase-9
}

\author{
Ya-Mei $\mathrm{Yu}^{1}{ }^{*}$, Hsing-Chun $\operatorname{Lin}^{2}$ and Weng-Cheng Chang ${ }^{1}$ \\ ${ }^{1}$ Department of Health Science, Chang Jung Christian University, 396 Chang Jung Rd., Sec. 1, Kway Jen, Tainan 71101, Taiwan \\ ${ }^{2}$ Department of Nutrition, China Medical University, 91 Hsueh-Shih Road, Taichung 40402, Taiwan
}

(Received 26 September 2007 - Revised 17 December 2007 - Accepted 2 January 2008 - First published online 26 February 2008)

The migration and matrix metalloproteinase (MMP) activation of vascular smooth muscle cells may play key roles in the development of atherosclerosis. Carnosic acid (CA) is a phenolic compound found in herbs, including rosemary and sage. Previous studies indicated that CA possesses antioxidant activity in vitro. In this study, we investigated the effects of CA on TNF- $\alpha$-induced cell migration, the formation of intracellular reactive oxygen species, the translocation of NF- $\mathrm{KB}$ and the activation and expression of MMP-9 in human aortic smooth muscle cells (HASMC). The Matrigel migration assay showed that CA (10 and $20 \mu \mathrm{mol} / \mathrm{l})$ effectively inhibited TNF- $\alpha$-induced migration of HASMC as compared with the control group. To explain this inhibitory effect, MMP-9 was assayed by gelatin zymography and Western blot. The results indicated that CA inhibited MMP-9 activity and expression. Furthermore, the production of reactive oxygen species and the nuclear translocation of NF- $\mathrm{B}$ p50 and p65 induced by TNF- $\alpha$ were dose-dependently suppressed by CA pretreament. These results indicate that CA has anti-inflammatory properties and may prevent the migration of HASMC by suppressing MMP-9 expression through down-regulation of NF- $\kappa \mathrm{B}$.

Carnosic acid: Human aortic smooth muscle cells migration: Matrix metalloproteinase-9: NF-кB: Atherosclerosis

Atherosclerosis is a progressive pathological disorder that often leads to CVD and cerebrovascular diseases. Despite improved pharmacological agents and changes in lifestyle, atherosclerosis is still a leading cause of mortality and morbidity in industrialized countries ${ }^{(1)}$. This chronic inflammatory disease is driven by risk factors that cause oxidative and inflammatory mechanisms ${ }^{(2)}$. Oxidative stress may trigger many cellular events, such as the inactivation of NO, oxidative modifications of DNA, proteins and lipids, and enhanced mitogenicity and apoptosis of vascular cells ${ }^{(3)}$. Furthermore, oxidative stress can also activate or increase the expression of redox-sensitive genes, such as those coding for oxidized LDL receptors, adhesion molecules, chemotaxis factors, proinflammatory cytokines, regulators of cell cycle progression and matrix metalloproteinases (MMP) $)^{(4)}$. Previous studies have also indicated that proinflammatory cytokines, such as TNF and IL-1, play an important role in the pathogenesis of atherosclerosis $^{(5,6)}$.

The migration of smooth muscle cells (SMC) from the tunica media to the subendothelial region is a key event in the development and progression of many vascular diseases, including atherosclerosis and post-angioplasty restenosis ${ }^{(7)}$. Activation of MMP may contribute to the pathogenesis of atherosclerosis by facilitating migration of $\mathrm{SMC}^{(8)}$. Analysis of human atherosclerotic lesions and advanced plaques has indicated an increased expression of MMP, especially the gelatinases MMP-2 and MMP-9, predominantly in vascular $\mathrm{SMC}^{(9)}$.

The pathogenesis of atherosclerosis also involves the transcription factor NF- $\kappa \mathrm{B}$, and its target genes ${ }^{(10)}$. NF- $\kappa \mathrm{B}$ subunits form homo- and heterodimers, with the most prominent being the p50/p65 heterodimer. The dimer is retained in the cytoplasm in an inactive state through interaction with inhibitory protein $\kappa \mathrm{B}^{(11)}$. NF- $\kappa \mathrm{B}$ is then rapidly activated in response to a variety of inflammatory and other stimuli that lead to the degradation of inhibitory protein $\kappa \mathrm{B}^{(12)}$. Upon activation of $\mathrm{NF}-\kappa \mathrm{B}$, a large number of genes are induced, including various inflammatory cytokines, adhesion molecules and $\mathrm{MMP}^{(12-14)}$.

$\mathrm{NF}-\kappa \mathrm{B}$ activation, which is followed in vitro by elevation in free radical levels, was demonstrated to be inhibited by antioxidants such as gallates, cafeic acid, curcumin and others ${ }^{(15-17)}$. Carnosic acid (CA), a major phenolic constituent in rosemary (Rosmarinus officinalis) and sage (Salvia officinalis) ${ }^{(18,19)}$, has a typical $O$-diphenol structure (Fig. 1). Most diphenol compounds have been shown to have potent chain-breaking antioxidant activity ${ }^{(20-22)}$. Previous studies have indicated that the extracts of rosemary and sage possess antioxidant, antimicrobial and anti-inflammatory effects ${ }^{(23,24)}$, and inhibit lipid absorption in $\operatorname{man}^{(25)}$. However, the effect of CA on the molecular mechanism of MMP-9 expression in cultured SMC has

Abbreviations: CA, carnosic acid; DPPH, 2,2-diphenyl-1-picrylhydrazyl; HASMC, human aortic smooth muscle cells; MMP, matrix metalloproteinase; MTT, 3-(4,5dimethylthiazol-2-yl)-2,5-diphenyl tetrazolium bromide; ROS, reactive oxygen species; SMC, smooth muscle cells; TEAC, Trolox equivalent antioxidant capacity; Tris-HCl, 2-amino-2-hydroxymethyl-1,3-propanediol hydrochloride.

* Corresponding author: Dr Ya-Mei Yu, fax +886 4 22478536, email yuyamei@hotmail.com 
<smiles>CC(C)c1cc2c(c(O)c1O)[C@]1(C(=O)O)CCCC(C)(C)[C]1CC2</smiles>

Fig. 1. The structure of carnosic acid.

not yet been elucidated. We hypothesized that TNF- $\alpha$-induced MMP-9 expression was abolished by CA in human aortic smooth muscle cells (HASMC) via inhibition of transcription factor NF- $\mathrm{BB}$ binding activities. Therefore, we investigated the effects of CA on TNF- $\alpha$-induced cell migration, the formation of intracellular reactive oxygen species (ROS), the translocation of NF- $\mathrm{kB}$, and the activation and expression of MMP-9 in HASMC.

\section{Materials and methods}

\section{2,2-Diphenyl-1-picrylhydrazyl scavenging assay}

The free radical scavenging effect was determined using the free radical generator 2,2-diphenyl-1-picrylhydrazyl (DPPH) proposed by Yamaguchi et al. ${ }^{(26)}$. Briefly, the reaction mixture contained $500 \mu \mathrm{l} \mathrm{CA}(0-200 \mu \mathrm{mol} / \mathrm{l})$ and $500 \mu \mathrm{l} \mathrm{DPPH}$ $(0.5 \mathrm{mmol} / 1$ in methanolic solution). The radical scavenging activity of DPPH was evaluated by measuring the change in absorbance at $517 \mathrm{~nm}$. Decoloration was plotted against the sample extract concentration in order to calculate the $\mathrm{IC}_{50}$ values (the amount of sample necessary to decrease the absorbance of DPPH by $50 \%$ ).

\section{Trolox equivalent antioxidant capacity assay}

The Trolox equivalent antioxidant capacity (TEAC) was determined according to the method of Miller et al. ${ }^{\text {(27). A }}$ value of 1 TEAC in a sample is defined as a concentration equivalent to $1(\mathrm{~mol} / \mathrm{l}$ Trolox, a water-soluble analogue of $\alpha$-tocopherol.

\section{Inhibition of $L D L$ oxidation}

LDL was isolated after ultracentrifugation as described previously ${ }^{(28)}$. The LDL fraction was dialysed against a PBS buffer of $\mathrm{pH} 7.4$ without EDTA in the dark, filtered through a $0.45 \mu \mathrm{m}$ filter, stored at $4^{\circ} \mathrm{C}$ under nitrogen, and used within $24-72 \mathrm{~h}$. The LDL was oxidized using classical copper-induced LDL auto-oxidation. Increasing concentrations of CA (approximately $0-10 \mu \mathrm{mol} / \mathrm{l}$ ) dissolved in dimethyl sulphoxide were added to the incubation media. Incubations were carried out at $37^{\circ} \mathrm{C}$ to measure the formation of conjugated dienes. Briefly, LDL total cholesterol $(0.9 \mathrm{mg} / \mathrm{ml})$ was incubated in PBS in the presence of $\mathrm{CuSO}_{4}$ $(50 \mu \mathrm{mol} / \mathrm{l})$. After incubation, $150 \mu \mathrm{l}$ EDTA $(2 \mathrm{mmol} / \mathrm{l})$ was added. A $100 \mu$ l portion of the mixture was then transferred to vials containing $0.9 \mathrm{ml}$ 2-propanol. The precipitates were removed via centrifugation. The concentration of conjugated diene in the supernatant was determined by measuring the absorption at $234 \mathrm{~nm}$.

\section{Cell culture}

HASMC were purchased from the Food Industry Research and Development Institute, Chin-Tsu, Taiwan (CCRC 60293). They were maintained in Ham's F12K medium containing $10 \%$ fetal bovine serum, $2 \mathrm{mmol} / \mathrm{l}$ L-glutamine, $1.5 \mathrm{~g} / \mathrm{l}$ sodium bicarbonate, $10 \mathrm{mmol} / 1$ HEPES, $10 \mathrm{mmol} / 1$ ( $N$-tris) hydroxymethy-2-aminoethanesulfonic acid, $0.05 \mathrm{mg} / \mathrm{ml}$ ascorbic acid, $0.01 \mathrm{mg} / \mathrm{ml}$ transferrin, $0.01 \mathrm{mg} / \mathrm{ml}$ insulin, $10 \mathrm{ng} / \mathrm{ml}$ sodium selenite and $0.03 \mathrm{mg} / \mathrm{ml}$ epidermal growth factor. All experiments were performed with HASMC in passages 21-31, which had been grown to $80-90 \%$ confluence and made quiescent by serum starvation ( $0.1 \%$ fetal bovine serum) for at least $24 \mathrm{~h}$.

\section{Cell viability assay using 3-(4,5-dimethylthiazol-2-yl)-2, 5-diphenyl tetrazolium bromide}

The cytotoxic effect of CA on HASMC was investigated using 3-(4,5-dimethylthiazol-2-yl)-2,5-diphenyl tetrazolium bromide (MTT) assay ${ }^{(29)}$. The principle of this assay is that mitochondria dehydrogenase in viable cells reduces MTT to a blue formazan product. Briefly, the cells were grown in ninetysix-well culture plates at a density of $1 \times 10^{4}$ cells per well in $\mathrm{F}-12 \mathrm{~K}$ culture medium and incubated with various concentrations of CA for $24 \mathrm{~h}$. Then, $10 \mu \mathrm{l}$ MTT $(5 \mathrm{mg} / \mathrm{ml})$ was added to each well and incubation was allowed to continue at $37^{\circ} \mathrm{C}$ for an additional $4 \mathrm{~h}$. The medium was then carefully removed, so that the formazan crystals that had formed were not disturbed. Dimethyl sulphoxide $(100 \mu \mathrm{l})$, which solubilizes formazan crystals, was added to each well, and absorbance of the solubilized blue formazan was measured at an optical density of $590 \mathrm{~nm}$ using the $\mu$ Quant Microplate Spectrophotometer (Bio-Tek, VT, USA). All determinations were performed according to three individual experiments. Each individual experiment included two duplicated experiments. The data are shown as means and standard deviations, as a percentage of the control.

\section{Examination of matrix metalloproteinase-9 by gelatin zymography}

MMP-9 activity in conditioned medium of cultured HASMC was analysed by substrate-gel electrophoresis (zymography) using SDS-PAGE $(10 \%)$ containing $0.1 \%$ gelatin. Substrate gel zymographic quantification of the activity of MMP-9 was performed with a Mini-Protein II apparatus from BioRad, according to a method described previously ${ }^{(30)}$. Cells were grown to sub-confluence, rinsed with PBS, and then incubated in serum-free medium for $24 \mathrm{~h}$. Equal volumes of samples of conditioned cell culture medium were mixed with sample buffer containing $62.5 \mathrm{mmol} / 1$ 2-amino-2-hydroxymethyl-1,3-propanediol hydrochloride (Tris-HCl) $(\mathrm{pH}$ 6.8 ), $10 \%$ glycerol, $2 \%$ SDS and $0.00625 \%$ (w/v) bromophenol blue, loaded on to the gel and separated by electrophoresis. 
Thereafter, gels were washed three times for $30 \mathrm{~min}$ at room temperature in buffer $(50 \mathrm{mmol} / \mathrm{l}$ Tris $-\mathrm{HCl}, \mathrm{pH} 8.0,5 \mathrm{mmol} / \mathrm{l}$ $\mathrm{CaCl}_{2}, 0.02 \% \mathrm{NaN}_{3}$ and $2.5 \%$ Triton $\mathrm{X}-100$ ) and incubated for $18 \mathrm{~h}$ at $37^{\circ} \mathrm{C}$ with the same buffer, minus Triton $\mathrm{X}-100$. Gels were stained with Coomasssie Brilliant Blue R-2500 $(0.1 \%)$ and destained in $5 \%$ methanol and $7 \%$ acetic acid. Gelatinolytic activity was represented as a clear band on a blue background.

\section{Western blot analysis for the expression of matrix} metalloproteinase-9

HASMC were treated with various concentrations of CA in the presence of $100 \mathrm{ng} / \mathrm{ml} \mathrm{TNF}-\alpha$. Cellular lysates were prepared in a lysis buffer containing $10 \mathrm{mmol} / \mathrm{l}$ Tris $-\mathrm{HCl}(\mathrm{pH} 8), 0 \cdot 32 \mathrm{~mol} / \mathrm{l}$ sucrose, $5 \mathrm{mmol} / \mathrm{l}$ EDTA, $1 \%$ Triton X-100, $2 \mathrm{mmol} / 1$ 1,4dithio-D,L-threitol and $1 \mathrm{mmol} / \mathrm{l}$ phenylmethylsulphonyl fluoride. The cells were disrupted and extracted at $4^{\circ} \mathrm{C}$ for $30 \mathrm{~min}$. After centrifugation at $13000 \mathrm{rpm}$ for $15 \mathrm{~min}$, the cell lysate was obtained as the supernatant. Protein concentrations were measured using the Bradford assay. Total protein $(20 \mu \mathrm{g})$ was subjected to SDS-PAGE (10\%) and blotted on polyvinylidene difluoride membranes. Soaking the membrane in PBS-Tween 20 buffer containing $50 \mathrm{~g} / \mathrm{l}$ non-fat milk blocked non-specific binding. The membrane was incubated with monoclonal mouse anti-human $\beta$-actin $(1: 1000)$ and polyclonal rabbit antihuman MMP-9 (1:1000). Subsequently, the membrane was incubated with sheep anti-mouse IgG antibody (1:5000) and goat anti-rabbit IgG antibody (1:5000) (Abcam, Cambridge, UK). The protein levels were determined using enhanced chemiluminescence detection reagents (Upstate, CA, USA) and highperformance chemiluminescence film (Amersham, IL, USA). Incubation with mouse anti-human $\beta$-actin antibody was also performed as an internal control. Results were quantified with a scanning densitometer using an image analysis system with software.

\section{ELISA-based NF- $\kappa B$ assay}

In addition to gel-shift assays, an ELISA-based kit was used for quantitative detection of NF- $\mathrm{KB}$ activity. Nuclear protein extracts of HASMC were prepared using a Trans AM Nuclear Extract Kit (Trans AM, CA, USA). For each sample, $20 \mu \mathrm{l}$ of nuclear extracts $(5 \mu \mathrm{g}$ protein) were used according to the manufacturer's instructions. Nuclear extracts were incubated in the oligonucleotide-coated wells for $60 \mathrm{~min}$. Where indicated, a competitor for NF- $\kappa \mathrm{B}$ binding (NF- $\kappa \mathrm{B}$ wild-type consensus oligonucleotide) was added in molar excess prior to the probe. The wells were then washed and incubated with the primary antibodies for p50 and p65 for $60 \mathrm{~min}$. After incubation with a horseradish peroxidase-conjugated secondary antibody, a substrate was added to produce a colour reaction; the reaction was quantitated by a $\mu$ Quant Microplate Spectrophotometer (Bio-Tek). The absorbance was read at $590 \mathrm{~nm}$ and the blank was subtracted from all measurements.

\section{Cell migration assay}

The invasion of vascular SMC through the extracellular matrix was determined by a commercial cell invasion assay kit (Chemicon, CA, USA $)^{(31)}$. HASMC $\left(1.5 \times 10^{5}\right.$ cells $\left./ 300 \mu l\right)$ were resuspended in conditioned medium collected after pretreatment with CA and TNF- $\alpha$-treated cells for $23 \mathrm{~h}$, and added to the upper components of the migration chamber. Then, $500 \mu l$ of the same conditioned medium was added to the lower compartment of the migration chamber. Cells without TNF- $\alpha$-treated conditioned medium served as the control. The migration chambers were incubated at $37^{\circ} \mathrm{C}$ for $24 \mathrm{~h}$ in $5 \% \mathrm{CO}_{2}$. After incubation, the inserts were removed from the wells, and the cells on the upper side of the filter were removed using cotton swabs. The filters were fixed, and stained according to the manufacturer's instructions. Then, $100 \mu l$ of the dye mixture was transferred to a ninety-sixwell plate, and the optical density was measured at $560 \mathrm{~nm}$.

\section{Measurement of intracellular reactive oxygen species}

HASMC were pretreated with 10 and $20 \mu \mathrm{mol} / 1 \mathrm{CA}$ for $1 \mathrm{~h}$ and induced by TNF- $\alpha(100 \mathrm{ng} / \mathrm{ml})$ for $23 \mathrm{~h}$. The cells were then incubated for $30 \mathrm{~min}$ with $10 \mu \mathrm{mol} / \mathrm{l}$ 2,7-dichlorofluorescein diacetate, which is converted to dichlorofluorescein by intracellular esterase. The latter was then oxidized by ROS to the highly fluorescent dichlorofluorescein. The fluorescence of each dish was immediately analysed at an excitation wavelength of $485 \mathrm{~nm}$ and an emission wavelength of $528 \mathrm{~nm}$ by an FL $\times 800$ microplate fluorescence reader $(\text { Bio-Tek })^{(32)}$. All measurements were at least triplicated.

\section{Statistical analyses}

Results are shown as means and standard deviations. Statistical analyses of MTT were performed using one-way ANOVA followed by Dennett's test; the other analyses were performed using one-way ANOVA followed by Duncan's multiple range test. A value of $P<0.05$ was considered statistically significant.

\section{Results}

The antioxidative capacity of carnosic acid in vitro

The free radical scavenging effect of CA was determined using the free radical generator DPPH; the $\mathrm{IC}_{50}$ of the DPPH assay was 35.9 (SD 1.7) $\mu \mathrm{mol} / \mathrm{l}$ (Table 1). The LDL oxidation assay was inhibited by $\mathrm{CA}$ and the $\mathrm{IC}_{50}$ of the inhibited LDL oxidation was 5.63 (SD 0.19) $\mu \mathrm{mol} / \mathrm{l}$ (Table 1). The TEAC assay is based on the reduction of the $2,2^{\prime}$-azino-bis

Table 1. Antioxidative capacity of carnosic acid in vitro* (Mean values and standard deviations for three determinations)

\begin{tabular}{|c|c|c|c|c|c|c|}
\hline & \multicolumn{2}{|c|}{$\begin{array}{l}\text { Inhibition of } \\
\text { LDL oxidation } \\
\left(\mathrm{IC}_{50}, \mu \mathrm{mol} / \mathrm{l}\right)\end{array}$} & \multicolumn{2}{|c|}{$\begin{array}{l}\text { DPPH rad- } \\
\text { icals scaven- } \\
\text { ging ability } \\
\left(\mathrm{I} \mathrm{C}_{50}, \mu \mathrm{mol} / \mathrm{l}\right)\end{array}$} & \multicolumn{2}{|c|}{ TEAC assay } \\
\hline & Mean & SD & Mean & $\mathrm{SD}$ & Mean & SD \\
\hline Carnosic acid & $5 \cdot 63$ & 0.19 & $35 \cdot 9$ & $1 \cdot 7$ & $5 \cdot 75$ & 0.49 \\
\hline
\end{tabular}

DPPH, 2,2-diphenyl-1-picrylhydrazyl; TEAC, Trolox equivalent antioxidant capacity. ${ }^{*}$ For details of procedures, see Materials and methods $I_{50}$ values were obtained from the concentration response curves. 
(3-ethylbenzthiazolien-6-sulfonic acid) radical cation by antioxidants; the TEAC value of CA was 5.75 (SD 0.49) (Table 1).

\section{Concentrations of carnosic acid for human aortic smooth} muscle cells

The cytotoxicity of CA on HASMC was evaluated using the MTT assay. CA had a dose-dependent cytotoxic effect on HASMC. After $24 \mathrm{~h}$ incubation with $0,10,20,30,50$ and 75 (mol/l CA, cell viability was 100, 94.9 (SD 1.2), 92 (SD $0.5), 84.9$ (SD 0.6), 79.7 (SD 1.6) and 67.7 (SD 2.6) \%, respectively, of the control level. Therefore, according to the MTT assay, we chose 10 and $20 \mu \mathrm{mol} / \mathrm{l} \mathrm{CA}$ to perform all of the following experiments.

Carnosic acid prevents TNF- $\alpha$-induced activation of matrix metalloproteinase-9 in human aortic smooth muscle cells

The effect of CA on TNF- $\alpha$-induced MMP-9 activation was analysed by gelatin zymography. As shown in Fig. 2, MMP-9 secretion was markedly induced by $\mathrm{TNF}-\alpha$, and suppressed by CA pretreatment. The $20 \mu \mathrm{mol} / \mathrm{l} \mathrm{CA}$ treatment was more effective at inhibiting the activation of MMP-9 than the $10 \mu \mathrm{mol} / \mathrm{l} \mathrm{CA}$ treatment.

Carnosic acid suppresses $T N F$ - $\alpha$-induced matrix metalloproteinase-9 expression in human aortic smooth muscle cells

The effect of MMP-9 expression by CA in vascular SMC was assessed by Western blot. HASMC were pretreated with 10

(A)


Fig. 2. Effect of carnosic acid (CA) on the matrix metalloproteinase-9 (MMP-9) activity of TNF- $\alpha$-induced human aortic smooth muscle cells (HASMC). HASMC were pretreated with 10 and $20 \mu \mathrm{mol} / / \mathrm{CA}$ for $1 \mathrm{~h}$, and induced by TNF- $\alpha(100 \mathrm{ng} / \mathrm{ml})$ for an additional $23 \mathrm{~h}$. (A), The activation of MMP-9 was assessed by gelatin zymography. (B), Densitometric analysis was conducted with image analysis system software to quantify gelatin zymography data. Values are means with their standard deviations depicted by vertical bars $(n 3)$. Each individual experiment included two duplicated experiments. ${ }^{a-d}$ Mean values with unlike letters were significantly different $(P<0.05)$. C, control without TNF- $\alpha$ or $\mathrm{CA}$; CA10, $10 \mu \mathrm{mol} / \mathrm{l} \mathrm{CA}$; CA20, $20 \mu \mathrm{mol} / \mathrm{l} \mathrm{CA}$; TNF, TNF- $\alpha$ and $20 \mu \mathrm{mol} / \mathrm{l} \mathrm{CA}$ for $1 \mathrm{~h}$, and induced by TNF- $\alpha(100 \mathrm{ng} / \mathrm{ml})$ for $23 \mathrm{~h}$. MMP-9 expression was markedly induced by TNF- $\alpha$, and suppressed by CA pretreatment (Fig. 3).

Carnosic acid suppresses nuclear translocation of $N F-\kappa B$ p50 and p65 in TNF- $\alpha$-induced human aortic smooth muscle cells

To determine whether the inhibitory effect of CA on the TNF$\alpha$-induced expression of MMP-9 is medicated via NF- $\mathrm{B}$, we measured the nuclear translocation of p50 and p65 of the NF-кB family. Treatment of TNF- $\alpha(100 \mathrm{ng} / \mathrm{ml})$ for $23 \mathrm{~h}$ enhanced the nuclear translocation of p50 (Fig. 4) and p65 (Fig. 5). Pretreatment of HASMC with 10 and $20 \mu \mathrm{mol} / \mathrm{l} \mathrm{CA}$ prior to TNF- $\alpha$ stimulation significantly prevented the nuclear translocation of p50 and p65. In Fig. 4, the $20 \mu \mathrm{mol} / \mathrm{l} \mathrm{CA}$ treatment was more effective at decreasing nuclear translocation of NF- $\mathrm{BB}$ p65 than the $10 \mu \mathrm{mol} / \mathrm{l} \mathrm{CA}$ treatment.

Carnosic acid suppresses TNF- $\alpha$-induced human aortic smooth muscle cell migration

As shown in Fig. 6, the migration of HASMC increased after treatment with $\mathrm{TNF}-\alpha$ relative to that of TNF- $\alpha$-untreated control cells. The stimulatory effect of TNF- $\alpha$ significantly decreased after CA pretreatment. The $20 \mu \mathrm{mol} / \mathrm{l} \mathrm{CA}$ treatment was more effective on decreasing the level of HASMC migration than the $10 \mu \mathrm{mol} / \mathrm{l} \mathrm{CA}$ treatment.

(A)
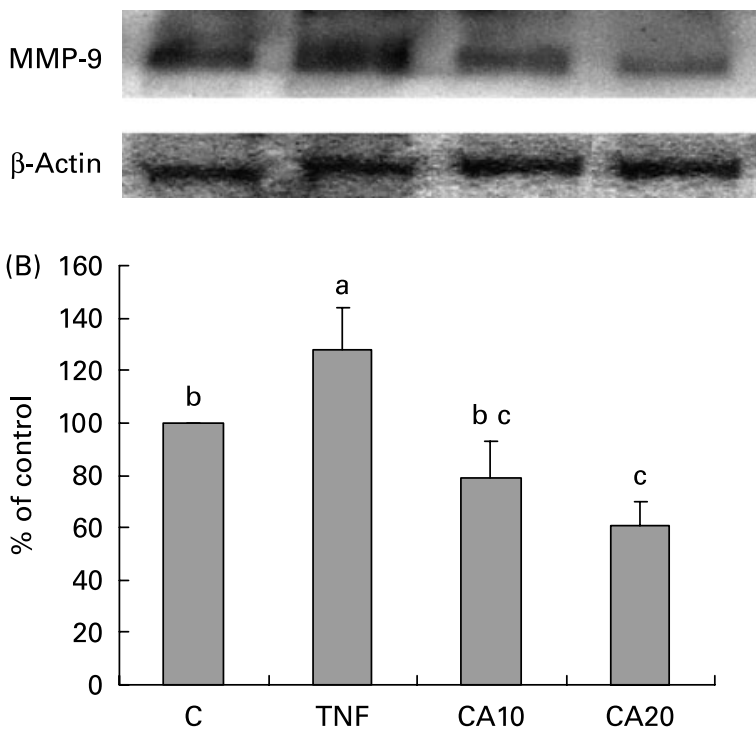

Fig. 3. Carnosic acid (CA) inhibits the protein expression of matrix metalloproteinase-9 (MMP-9) in human aortic smooth muscle cells (HASMC). HASMC were pretreated with 10 and $20 \mu \mathrm{mol} / / \mathrm{CA}$ for $1 \mathrm{~h}$, and induced by TNF- $\alpha(100 \mathrm{ng} / \mathrm{ml})$ for an additional $23 \mathrm{~h}$. The expression of MMP-9 was assessed by Western blot analysis. (A), Representative Western blot showing MMP-9 protein levels in cell lysates (top) and $\beta$-actin (bottom). (B), Densitometric analysis was conducted with image analysis system software to quantify Western blot data. Values are means with their standard deviations depicted by vertical bars ( $n 3$ ). Each individual experiment included two duplicated experiments. ${ }^{a, b, c}$ Mean values with unlike letters were significantly different $(P<0.05)$. C, control without TNF- $\alpha$ or CA; CA10, $10 \mu \mathrm{mol} / / \mathrm{CA}$; CA20, $20 \mu \mathrm{mol} / \mathrm{I} \mathrm{CA}$; TNF, TNF- $\alpha$ 


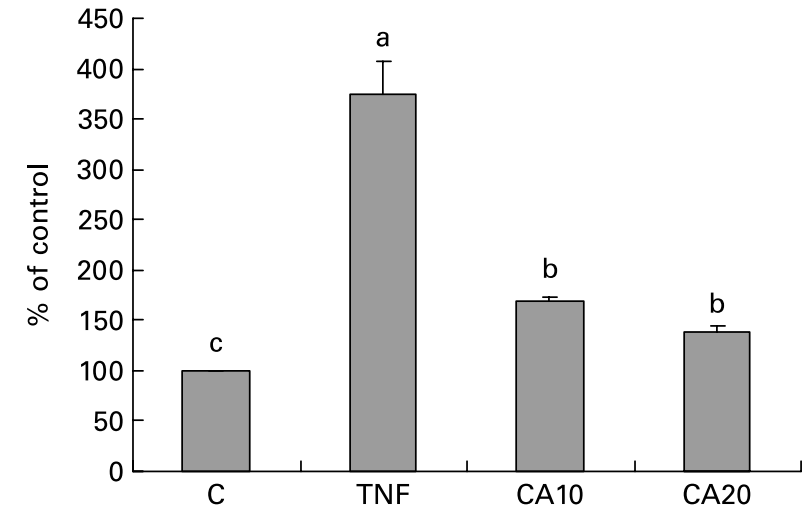

Fig. 4. Effect of carnosic acid (CA) on TNF- $\alpha$-induced activation of NF-кB p50 in human aortic smooth muscle cells (HASMC). HASMC were pretreated with 10 and $20 \mu \mathrm{mol} / \mathrm{l} \mathrm{CA}$ for $1 \mathrm{~h}$ and induced by TNF- $\alpha(100 \mathrm{ng} / \mathrm{ml})$ for $23 \mathrm{~h}$. Nuclear extracts were prepared and analysed for activation of the NF- $\mathrm{kB}$ family; $5 \mu \mathrm{g}$ nuclear protein were used in each experiment. Values are means with their standard deviations depicted by vertical bars $(n 3)$. Each individual experiment included two duplicated experiments. ${ }^{\text {a,b,c }}$ Mean values with unlike letters were significantly different $(P<0.05)$. C, control without TNF- $\alpha$ or CA; CA10, $10 \mu \mathrm{mol} / \mathrm{l} \mathrm{CA}$; CA20, $20 \mu \mathrm{mol} / \mathrm{l} \mathrm{CA}$; TNF, TNF- $\alpha$.

\section{Carnosic acid suppresses $T N F$ - $\alpha$-induced reactive oxygen} species generation

The production of ROS was induced by TNF- $\alpha$ and decreased by CA. The $20 \mu \mathrm{mol} / 1 \mathrm{CA}$ treatment was more effective at reducing ROS generation than the $10 \mu \mathrm{mol} / \mathrm{l} \mathrm{CA}$ treatment (Fig. 7).

\section{Discussion}

In the present study, we investigated the effect of CA on HASMC migration and TNF- $\alpha$-induced MMP-9 activation. Gelatin zymography and Western blot assays revealed that CA lowered the level of secretion and protein expression of MMP-9, as well as suppressed the nuclear translocation of the NF- $\mathrm{B}$ p50 and p65. In addition, CA effectively inhibited the TNF- $\alpha$-induced migration of HASMC.

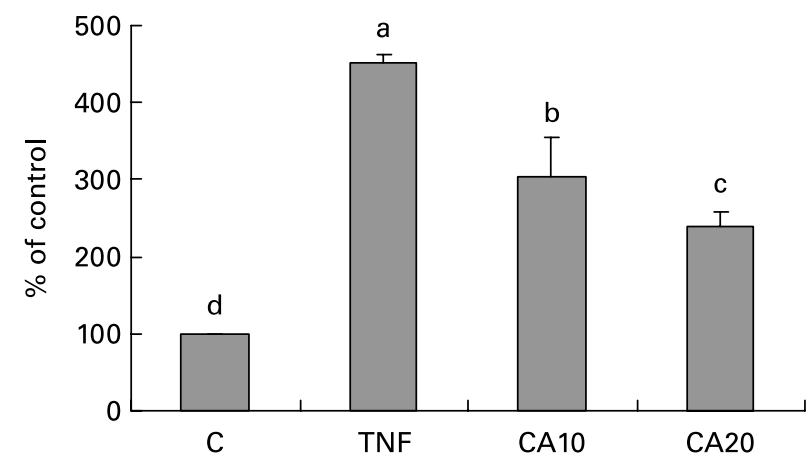

Fig. 5. Effect of carnosic acid (CA) on TNF- $\alpha$-induced activation of NF-кB p65 in human aortic smooth muscle cells (HASMC). HASMC were pretreated with 10 and $20 \mu \mathrm{mol} / / \mathrm{CA}$ for $1 \mathrm{~h}$ and induced by TNF- $\alpha(100 \mathrm{ng} / \mathrm{ml})$ for $23 \mathrm{~h}$. Nuclear extracts were prepared and analysed for activation of the NF- $\mathrm{kB}$ family; $5 \mu \mathrm{g}$ nuclear protein were used in each experiment. Values are means with their standard deviations depicted by vertical bars $(n 3)$. Each individual experiment included two duplicated experiments. ${ }^{a-d}$ Mean values with unlike letters were significantly different $(P<0.05)$. C, control without TNF- $\alpha$ or CA; CA10, $10 \mu \mathrm{mol} / \mathrm{l} \mathrm{CA}$; CA20, $20 \mu \mathrm{mol} / \mathrm{l} \mathrm{CA}$; TNF, TNF- $\alpha$.

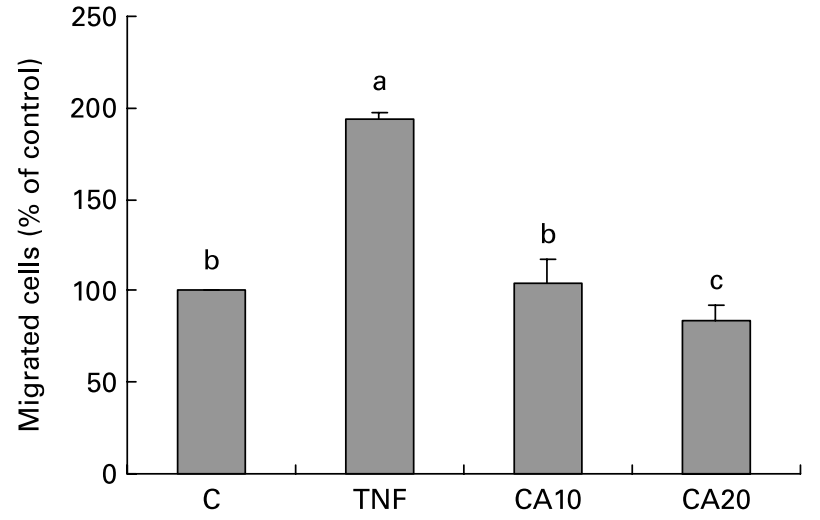

Fig. 6. Effect of carnosic acid (CA) on migration of human aortic smooth muscle cells (HASMC) induced by TNF- $\alpha$ treatment. HASMC $\left(1.5 \times 10^{5}\right.$ cells $/ 300 \mu \mathrm{l})$ were resuspended in a conditioned medium after treatment with TNF- $\alpha$ for $23 \mathrm{~h}$, and added to the upper components of the migration chamber in the presence of 10 and $20 \mu \mathrm{mol} / \mathrm{l} \mathrm{CA}$. Values are means with their standard deviations depicted by vertical bars $(n 3)$. Each individual experiment included two duplicated experiments. ${ }^{a, b, c}$ Mean values with unlike letters were significantly different $(P<0.05)$. C, control without TNF- $\alpha$ or CA; CA10, $10 \mu \mathrm{mol} / \mathrm{I} \mathrm{CA}$; CA20, $20 \mu \mathrm{mol} / / \mathrm{CA}$; TNF, TNF- $\alpha$.

Sage (S. officinalis) and rosemary (R. officinalis) are Labiatae herbs commonly used in cooking and folk medicines around the world ${ }^{(21)}$. CA is a phenolic diterpene compound found in sage $(2-5 \mathrm{mg} \mathrm{CA} / \mathrm{g}$ sage) and rosemary $(12-15 \mathrm{mg}$ $\mathrm{CA} / \mathrm{g}$ rosemary $)^{(18,19)}$. It is a lipophilic antioxidant that scavenges singlet oxygen, hydroxyl radicals and lipid peroxyl radicals, thus preventing lipid peroxidation ${ }^{(20-22)}$. In the present in vitro study, we found that CA could scavenge DPPH radicals, alkoxyl radicals (RO) and lipid peroxyl radicals (ROO) (Table 1). Furthermore, we found that CA has the ability to suppress TNF- $\alpha$-induced intracellular ROS production (Fig. 7), and that its antioxidative ability is approximately 5-6-fold more potent than Trolox (Table 1).

The migration of SMC from the tunica media to the subendothelial region is a key event in the development and progression of atherosclerosis ${ }^{(7)}$. MMP (MMP-2 and MMP-9) activity may contribute to the pathogenesis of atherosclerosis by facilitating the migration of $\mathrm{SMC}^{(8)}$. Although MMP-2 and MMP-9 have similar substrate specificities, the regulation of their expression is different. MMP-2 is constitutively expressed in several cell types, including SMC, and its expression is not induced by cytokines or growth factors. In contrast, MMP-9 can be induced by TNF- $\alpha$ in $S_{M C}^{(33,34)}$ Therefore, we have investigated the effect of CA on TNF$\alpha$-induced SMC migration and activation of MMP-9. The present results indicate that the migration of HASMC is significantly induced by TNF- $\alpha$ and suppressed by 10 and $20 \mu \mathrm{mol} /$ 1 CA pretreatment (Fig. 6). This inhibition of TNF- $\alpha$-induced migration of HASMC is consistent with the inhibition of activation and expression of MMP-9 (Figs. 2 and 3). Similar results were seen when SMC were pretreated with other polyphenolic compounds, such as tea flavonoid epigallocatechin-3-gallate $(20 \mu \mathrm{mol} / \mathrm{l})$, quercetin $(40 \mu \mathrm{mol} / \mathrm{l})$ and other flavonoids ${ }^{(35-37)}$.

Further research beyond the scope of the present study is necessary to elucidate the mechanisms underlying the synergistic regulation of MMP secretion by cytokines. In the 
(A)


(c)

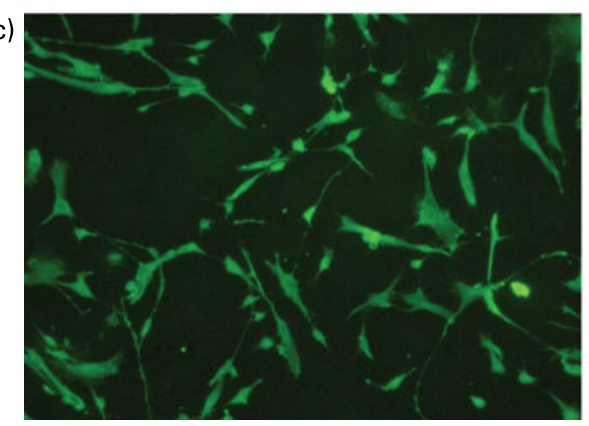

(d)





Fig. 7. Effect of carnosic acid (CA) on TNF- $\alpha$-induced reactive oxygen species (ROS) production in human aortic smooth muscle cells (HASMC). (A), Microphotograph of ROS production in HASMC without TNF- $\alpha$ or CA (a), with TNF- $\alpha$ (100 ng/ml) (b), with TNF- $\alpha(100 \mathrm{ng} / \mathrm{ml}) \mathrm{and} 10 \mu \mathrm{mol} / \mathrm{l} \mathrm{CA} \mathrm{(c),} \mathrm{with} \mathrm{TNF-} \alpha$ (100 ng/ml) and $20 \mu \mathrm{mol} / \mathrm{l} \mathrm{CA}$ (d). (B), HASMC were pretreated with 10 and $20 \mu \mathrm{mol} / \mathrm{l} \mathrm{CA}$ for $1 \mathrm{~h}$ and induced by TNF- $\alpha(100 \mathrm{ng} / \mathrm{ml})$ for $23 \mathrm{~h}$. Values are means with their standard deviations depicted by vertical bars $(n 3)$. Each individual experiment included two duplicated experiments. ${ }^{a, b, c}$ Mean values with unlike letters were significantly different $(P<0.05)$. C, control without TNF- $\alpha$ or CA; CA10, $10 \mu \mathrm{mol} / \mathrm{l} \mathrm{CA}$; CA20, $20 \mu \mathrm{mol} / \mathrm{l} \mathrm{CA}$; TNF, TNF- $\alpha$.

present study, we focused instead on defining the role played by the NF-kB transcription factor in the regulation of MMP in HASMC. A functional NF- $\mathrm{B}$ site occurs in the proximal stimulatory region of the MMP-9 promoter $^{(38,39)}$, and deletion of this site reduces up-regulation of reporter gene constructs in response to cytokines. Until now, however, it has been unclear as to the role NF- $\kappa \mathrm{B}$ plays in the up-regulation of the endogenous MMP-9 gene. Bond et al. ${ }^{(40)}$ have demonstrated that transient overexpression of inhibitory protien $\kappa \mathrm{B} \alpha$ in vascular SMC only partially impaired up-regulation of MMP-9, suggesting that NF- $\mathrm{B}$ might play a simple permissive role. In the present study, CA reduced cytokineinduced expression of MMP-9 and prevented the nuclear translocation of p50 (Fig. 4) and p65 (Fig. 5) in HASMC.
We suggest that inhibitory mechanisms of CA might interrupt a signalling cascade involving MMP-9 transcription-mediated activation of NF-кB.

Several studies have indicated that ROS are implicated in the activation of NF- $\mathrm{B}^{(3)}$. The current study showed that CA pretreatment in HASMC decreased the TNF- $\alpha$-stimulated production of ROS (Fig. 7). Based on this result, we propose that the inhibitory effect of CA on MMP-9 expression and NF- $\kappa \mathrm{B}$ activation may be due to its antioxidant and antiinflammatory properties. Since atherosclerosis is a chronic inflammatory disease associated with increased oxidative stress in HASMC, it would be conceivable that the antiatherogenic effects of CA might be caused by its antioxidative and anti-inflammatory properties. 
In conclusion, $\mathrm{CA}$ effectively inhibited the TNF- $\alpha$-induced migration of HASMC. The levels of ROS production, MMP-9 activation and expression, and nuclear translocation of NF- $\kappa \mathrm{B}$ p50 and p65 were also all reduced by CA pretreatment. The present results led us to conclude that CA inhibits TNF- $\alpha$-induced nuclear translocation of p50 and p65, thereby suppressing the activation and protein expression of MMP-9, resulting in decreased HASMC migration. Thus, CA may play an important role in the prevention of atherosclerosis.

\section{Acknowledgements}

This work was supported by the National Science Council of Taiwan (NSC 96-2320-B-309-004-MY2). There is no conflict of interest. All of the authors have contributed substantially to the manuscript. The authors would like to thank Margaret Chang for preparation of this manuscript.

\section{References}

1. Braunwald E (1997) Shattuck lecture - Cardiovascular medicine at the turn of the millennium: triumphs, concerns, and opportunities. N Engl J Med 337, 1360-1369.

2. Kaperonis EA, Liapis CD, Kakisis JD, Dimitroulis D \& Papavassiliou VG (2006) Inflammation and atherosclerosis. Eur J Vasc Endovasc Surg 31, 386-393.

3. Muller JM, Rupec RA \& Baeuerle PA (1997) Study of gene regulation by NF-kappa B and AP-1 in response to reactive oxygen intermediates. Methods 11, 301-312.

4. Wassmann S, Wassmann K \& Nickenig G (2004) Modulation of oxidant and antioxidant enzyme expression and function in vascular cells. Hypertension 44, 381-386.

5. Zhu Y, Liao HL, Lin JHC, Verna L \& Stemerman MB (1999) Low-density lipoprotein augments interleukin-1-induced vascular adhesion molecule expression in human endothelial cells. Atherosclerosis 144, 357-365.

6. Rahman A, Kefer J, Bando M, Niles WD \& Malik AB (1998) E-selectin expression in human endothelial cells by TNFalpha-induced oxidant generation and NF-kappaB activation. Am J Physiol 275, 533-544.

7. Maeda K, Kuzuya M, Cheng XW, Asai T, Kanda S, Tamayamori N, Sasaki T, Shibata T \& Iguchi A (2003) Green tea catechins inhibit the cultured smooth muscle cell invasion through the basement barrier. Atherosclerosis 166, 23-30.

8. Jones CB, Sane DC \& Herrington DM (2003) Matrix metalloproteinases: a review of their structure and role in acute coronary syndrome. Cardiovasc Res 59, 812-823.

9. Galis ZS, Johnson C, Godin D, Magid R, Shipley JM, Senior RM, Ivan E, et al. (2002) Targeted disruption of the matrix metalloproteinase-9 gene impairs smooth muscle cell migration and geometrical arterial remodeling. Circ Res 91, 852-859.

10. Kutuk O \& Basaga $H$ (2003) Inflammation meets oxidation: $\mathrm{NF}-\kappa \mathrm{B}$ as a mediator of initial lesion development in atherosclerosis. Trends Mol Med 9, 549-557.

11. Barnes PJ \& Adcock IM (1997) NF-kappa B: a pivotal role in asthma and a new target for therapy. Trends Pharmacol Sci 18, 46-50.

12. De Martin R, Hoeth M, Hofer-Warbinek R \& Schmid JA (2000) The transcription factor NF- $\mathrm{KB}$ and the regulation of vascular cell function. Arterioscler Thromb Vasc Biol 20, E83-E88.

13. Baeuerle PA (1991) The inducible transcription activator NFкB: regulation by distinct protein subunits. Biochim Biophys Acta 1072, 63-80.
14. Neish AS, Williams AJ, Palmer HJ, Whitley MZ \& Clollins T (1992) Functional analysis of the human vascular cell adhesion molecule-1 promoter. J Exp Med 176, 1583-1593.

15. Murase T, Kume N, Hase T, Shibuya Y, Nishizawa Y, Tokimitsu I \& Kita T (1999) Gallates inhibit cytokine-induced nuclear translocation of NF-kappaB and expression of leukocyte adhesion molecules in vascular endothelial cells. Arterioscler Thromb Vasc Biol 19, 1412-1420.

16. Natarajan K, Singh S, Burke TR Jr, Grunberger D \& Aggarwal BB (1996) Caffeic acid phenethyl ester is a potent and specific inhibitor of activation of nuclear transcription factor NF-kappa B. Proc Natl Acad Sci U S A 93, 9090-9095.

17. Chan MM (1995) Inhibition of tumor necrosis factor by curcumin, a phytochemical. Biochem Pharmacol 49, 1551-1556.

18. Luis JC, Martin Perez R \& Valdes Gonzalez F (2007) UV-B radiation effects on foliar concentrations of rosmarinic and carnosic acids in rosemary plants. Food Chem 101, 1211-1215.

19. Baskan S, Oztekin N \& Erim B (2007) Determination of carnosic acid and rosmarinic acid in sage by capillary electrophoresis. Food Chem 101, 1748-1752.

20. Shahidi F, Janitha PK \& Wanasundara PD (1992) Phenolic antioxidants. Crit Rev Food Sci Nutr 32, 67-103.

21. Masuda T, Inaba Y \& Takeda Y (2001) Antioxidant mechanism of carnosic acid: structural identification of two oxidation products. J Agric Food Chem 49, 5560-5565.

22. del Bano MJ, Lorente J, Castillo J, Benavente-Garcia O, del Rio JA, Ortunto A, Quirin KW \& Gerard D (2003) Phenolic diterpenes, flavones, and rosmarinic acid distribution during the development of leaves, flowers, stems, and roots of Rosmarinus officinalis. J Agric Food Chem 51, 4247-4253.

23. Oluwatuyi M, Kaatz GW \& Gibbson S (2004) Antibacterial and resistance modifying activity of Rosmarinus officinalis. Phytochemistry 65, 3249-3254.

24. Moreno S, Scheyer T, Romano CS \& Vpjnov AA (2006) Antioxidant and antimicrobial activities of rosemary extracts linked to their polyphenol composition. Free Radic Res 40, $223-231$.

25. Ninomiya K, Matsuda H, Shimoda H, Nishida N, Kasajima N, Yoshino T, Morikawa T \& Yoshikawa M (2004) Carnosic acid, a new class of lipid absorption inhibitor from sage. Bioorg Med Chem Lett 14, 1943-1946.

26. Yamaguchi T, Takamura H, Matoba T \& Terao J (1998) HPLC method for evaluation of the free radical-scavenging activity of foods by using 1,1-dipheny-2-picrylhydrazyl. Biosci Biotechnol Biochem 62, 1201-1204.

27. Miller NJ, Rice-Evans C, Davies MJ, Gopinathan V \& Miller AA (1993) A novel method for measuring antioxidant capacity and its application to monitoring the antioxidant status in premature neonates. Clin Sci 84, 407-412.

28. Mackness MI \& Durringtom PN (1992) Lipoprotein separation, analysis for clinical studies. In Lipoprotein Analysis: A Practical Approach, pp. 1-42 [CA Converse and ER Skinner, editors]. Oxford: IRL Press.

29. Chen YH, Lin SJ, Chen JW, Ku HH \& Chen YL (2002) Magnolol attenuates VCAM-1 expression in vitro in TNF- $\alpha$-treated human aortic endothelial cells and in vivo in the aorta of cholesterol-fed rabbits. Br J Pharmacol 135, 37-47.

30. Demeule M, Brossard M, Page M, Gingras D, Beliveau R, et al. (2000) Matrix metalloproteinase inhibition by green tea catechins. Biochim Biophys Acta 1478, 51-60.

31. Bedoui J, Oak MH, Anglard P \& Schini-Kerth VB (2005) Catechins prevent vascular smooth muscle cell invasion by inhibiting MT1-MMP activity and MMP-2 expression. Cardiovasc Res 67, 317-325.

32. Kim YM, Kim KE, Koh GY, Ho YS \& Lee KJ (2006) Hydrogen peroxide produced by angiopoietin-1 mediates angiogenesis. Cancer Res 66, 6167-6174. 
33. Cho A, Graves J \& Reidy MA (2000) Mitogen-activated protein kinases mediate matrix metalloproteinase-9 expression in vascular smooth muscle cells. Arterioscler Thromb Vasc Biol 20, $2527-2532$.

34. Galis ZS, Muszynski M, Sukhova GK, Simon-Morrissey E, Unemori EN, Lark MW, Amento E \& Libby P (1994) Cytokine stimulated human vascular smooth muscle cells synthesize a complement of enzymes required for extracellular matrix digestion. Circ Res 75, 181-189.

35. Kim CH \& Moon SK (2005) Epigallocatechin-3-gallate causes the p21/WAF1-mediated G1-phase arrest of cell cycle and inhibits matrix metalloproteinase-9 expression in TNF- $\alpha$-induced vascular smooth muscle cells. Arch Biochem Biophys 435, 264-272.

36. Moon SK, Cho GO, Jung SY, Gal SW, Kwon TK \& Lee YC (2003) Quercetin exerts multiple inhibitory effects on vascular smooth muscle cells: role of ERK1/2, cell cycle regulation, and matrix metalloproteinase-9. Biochem Biophys Res Commun 301, 1069-1078.

37. Kris-Etherton PM \& Keen CL (2002) Evidence that the antioxidant flavonoids in tea and cocoa are beneficial for cardiovascular health. Curr Opin Lipidol 13, 41-49.

38. Sato H \& Seiki M (1993) Regulatory mechanism of 92-kDa Type-IV collagenase gene expression which is associated with invasiveness of tumor cells. Oncogene 8, 395-405.

39. Fini ME, Bartlett JD, Matsubara M, et al. (1994) The rabbit gene for $92-\mathrm{kDa}$ matrix metalloproteinase: role of AP1 and AP2 in cell type-specific transcription. $J$ Biol Chem 269, 28620-28628.

40. Bond M, Chase AJ, Baker AH \& Newby AC (2001) Inhibition of transcription factor NF- $\mathrm{BB}$ reduces matrix metalloproteinase-1, -3 and -9 production by vascular smooth muscle cells. Cardiovasc Res 50, 556-565. 